\title{
A Modern Approach to Building Successful Online Brand Communities
}

\author{
Julio Viskovich \\ Continuing Sessional Lecturer, School of Business \& Economics, Thompson Rivers University, Canada
}

Corresponding author: Julio Viskovich, Continuing Sessional Lecturer, School of Business \& Economics, Thompson Rivers University, Canada. E-mail: jviskovich@tru.ca

Received: December: 31, 2019, Accepted: January: 06, 2020, Published: January: 10, 2020

Keywords: Online, Brand Communities, Social media -centric, Internet

\section{Introduction}

A brand community needs to be defined by exploring three different branded community models: traditional, social media-centric and a more innovative blend of online and offline that will provide modern methods to engage consumers that have embraced the Internet and have supported the social media.

The primary goal of communities is to turn loyal fans of a brand into brand advocates that become effective micro-marketers that advocate on behalf of the brand to their friends, family and online community. Think word-of-mouth on steroids.

The difference that social networks allow you to do versus traditional approaches is to hyper-target new or real-time current customers including those that are connected to your competitors. You can email them, but you can't really customize the experience, so you play by what Facebook or LinkedIn has given you as tools to use and engage. That's the challenge with social network communities today is that they are at the mercy of the day-to-day changes the social networks decide to implement. Brands have grown engaged audiences of millions and have had their organic reach refrained to $3-10 \%$ in some cases.

The Importance of Online Communities for Brands Research into brand community managers revealed that brand communities launch several marketing strategies to keep the users active and highly involved. Usually, we find that big brands or brands with high involvement of consumers has always eye-catching offers, discount coupons, and responsive behaviors towards the consumers who can be a user, client, customer, or visitor. This is a graphical representation of principal communication relationships in brand communities (Figure 1).

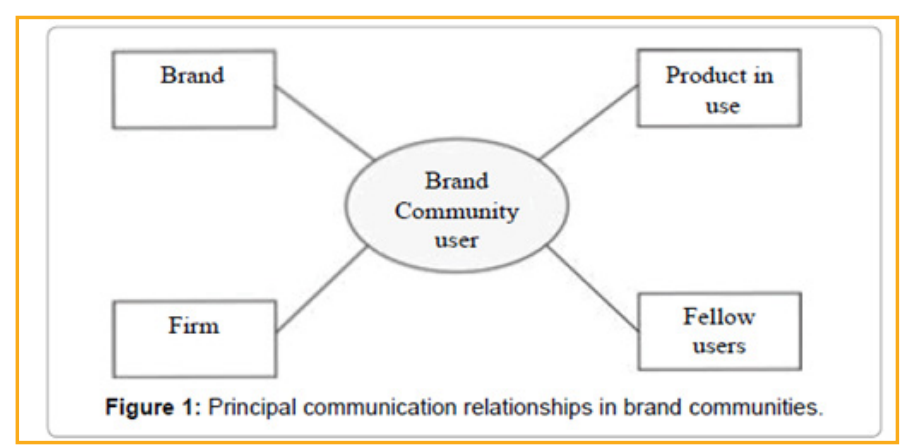




\section{Six Successful Example Online Brand Community}

Many successful sites that demonstrate brand community successes using systems that regularly include forms or sections that prompt communication with users, encouraging discussion and conversation around interests.

Based on this, the six examples of thriving brand communities are:

\section{Lego ideas}

Lego is an excellent example of a company that has combined people's passion for their products with an online community, using message boards as well as running competitions for users to design and submit their own ideas, sharing with others.

\section{Made unboxed}

Made unboxed gives users an understanding of how Made's products appear in real-life. Providing inspiration to shoppers, Made found a gap in the market, creating a similar experience to in-store shopping, online. With consumers preferring to purchase furniture seeing the items in realistic settings, an online showroom enabled viewers to do this, ordering from the comfort of their own homes.

\section{Figment}

Figment is a social network-style community that brings value to its visitors. With a target userbase of 13-18-year olds, areas to share opinions and creative content, users can submit their own stories, as well as enjoying others' creations.

\section{PlayStation community}

PlayStation's business model has successfully integrated gaming into many people's everyday lives through creating a gaming community that are also able to communicate and discuss gameplay.

\section{Beauty Talk}

Beauty Talk was an invention that came around after masses of frequently asked questions were left on the website Sephora.com. It builds in the requirement for the unbiased perception in the world of beauty. The main reason for its popularity is it's incredibly useful for answering product-related queries.

\section{Harley owners' group}

Tapping into bike enthusiasts' passion, Harley Davidson has created an exclusive members-only website that gives unique benefits. A close community, Harley Davidson owners were given the opportunity to make lifelong connections with people with similar interests, being proud of their lifestyle and organizing meet-ups on the Harley Owners Group.

\section{Best Practices for Online Brand Communities}

Branded online communities need to hold fan interest and drive advocacy on behalf of the brand but not like traditional communities and early social media communities. Brands have to do something even more unique and special that holds their audience's attention and also keeps them engaged. Brand fans want to be recognized if they're helping your team or your organization.

\section{Motivations for Consumers to join Online Brand Communities}

Consumers motivation is necessary for a brand to build it as big, to involve the consumers in the brand, and to engage people with interesting deals is a key to success for online brand communities. Generally, four motivations exist based on what consumers might join the community, all these four are discovered after reviewing a lot of literature. Following are the four motivations:

- Reassurance of quality and credence attributes

- High involvement with the branded product category

- Opportunity for consumer and brand interaction

- The brand's symbolic function

First of all, Quality reassurance can lead the brand community participation to the next level. It means the product should be classified as per credence quality, search, and experience to obtain the quality products. Brand communities are a sort of potential consumer group looking for credence product quality.

Secondly, a true consumer will always make an extensive search for the high-involvement product. That means quality can't be compromised when a group of potential consumers is going to take your services order.

Third, people seek the opportunity to interact with a brand as well as other consumers around the brand's specialized offering.

Fourth, brand symbolic function or brand identity. That gives a clear idea of the product or business as what's people are going on these platforms. Below is a representation of the given four Motives and their Dominant relationships for better understanding in graphical form Table 1. 
Citation: Julio Viskovich (2020 ) A Modern Approach to Building Successful Online Brand Communities. Journal of Media \& Management. SRC/JMM-104. DOI: doi.org/10.47363/JMM/2020(2)104

\begin{tabular}{|l|l|}
\hline Motive & Dominant Relationship \\
\hline Assurance for Credence Good & $\begin{array}{l}\text { Customer- Company Rela- } \\
\text { tionship }\end{array}$ \\
\hline $\begin{array}{l}\text { High Involvmentr in Product } \\
\text { Category }\end{array}$ & $\begin{array}{l}\text { Customer-Product Relation- } \\
\text { ship }\end{array}$ \\
\hline Joint Consumption & $\begin{array}{l}\text { Customer-customer relation- } \\
\text { ship }\end{array}$ \\
\hline Brand Symbol & Customer-brand relationship \\
\hline
\end{tabular}

Table 1: Motives and their dominant relationships.

\section{Key Take-Aways for Brand Community Builders}

With the continuous progression and growth in the interest and use of social media platforms, brands are always looking to grow their presence, creating dedicated followings or communities which can share and interact with content to increase brand reach and success. Developing advocates and a strong community can significantly contribute to brand value, eWOM (word of mouth on steroids) and ultimately sales [1-7].

\section{References}

1. Ansarin M, OzuemW (2015) Social Media and Online Brand Communities P27

2. Zaglia EM (2013) Brand communities embedded in social networks. J Bus Res 2: 216-223.

3. Nielson J (2006) Participation inequality: Encouraging more users to contribute.

4. Gilliland N (2017) Six successful examples of online brand communities.

5. Mangold GW (2009) Social media: The new hybrid element of the promotion mix. Business Horizons 52: 357-365.

6. Research Services (2018) Consumer Behaviour Studies: High-Involvement versus Low-Involvement.

7. Xiang Z, Gretzel U (2010) Role of social media in online travel information search. Tourism Manage 31: 179-188. 